\title{
リチゥムイオンニ次電池負極材料としての表面修飾炭素－䇪素化合物
}

\author{
中島 剛 ${ }^{*}$, 高 明天

\section{Surface-Modified Carbon-Nitrogen Compound as a Negative Electrode Material for Lithium Ion Secondary Battery}

\author{
Tsuyoshi NAKAJIMA* and Meiten $\mathrm{KOH}$
}

Received April 12, 1996 ; Accepted May 17, 1996

\begin{abstract}
1 緒鲁
リチウムイオン二次電池の負極におけるデンドライト生成 をさけるためリチウムの黒鉛層間化合物が負極としてもち いられており, 結晶性, 形態の異なる種々の炭素材料につい て数多くの研究結果が報告されている1,2). 炭素材料の結晶 性，表面糟情極特性を支配する重要な因子と考元られ，高 結晶性黒鉛，低結晶性炭素が大きな容量を示すことがすでに 知られている1,2). 更に最近炭素椪造中の炭素原子を一部ホ ウ素や窒素に置換した $\mathrm{BC}_{x} \mathrm{~N}, \mathrm{BC}_{\boldsymbol{x}}, \mathrm{C}_{\boldsymbol{x}} \mathrm{N}$ の合成之電気化学的 特性が報告された ${ }^{3-6)}$ ，これらの化合物は炭素の電子構造を 変えることによってリチウムとの化学的相互作用を変化させ る物質と考えることができる。これらの一群の化合物の中で 宸素一聜素化合物 $\mathrm{C}_{x} \mathrm{~N}$ はかなりの窒素原子が炭素シートの 周辺に存在し, 不可逆容量を増大させる原因となっており, $\mathrm{C}_{x} \mathrm{~N}$ は負極材料として不適と報告されている6)..しかしな がら，金属ニッケル粉末を触媒とするCVDによって合成し た $\mathrm{C}_{\boldsymbol{x}} \mathrm{N}$ は炭素シートの周辺に存在する空素が著しく少なく, かつ結鼠性も良好で, 更に表面処理を施すことによって優れ だ負極特性を示すことが見いだされたのでここに報告する．
\end{abstract}

\section{2 実験}

$\mathrm{C}_{x} \mathrm{~N}$ は市販の金属ニッケル粉末 (純度 $99 \%$ ，50mg) をア ルミナ製ボートにうすく広げ，アルミナ製反応管に入れた 後，市販のアセトニトリル (純度 $99 \%$ ) を窒素ガスをキャリ アガスとしてニッケル上に流して熱分解することによって 合成した，全流量は $55 \mathrm{ml} \mathrm{min} \mathrm{min}^{-1}$, アセトニトリルの分圧は $0.09 \mathrm{~atm}$, 熱分解温度は $800 \sim 1100{ }^{\circ} \mathrm{C}$ であり，12 時間の熱分 解反応で 400 500mg の $\mathrm{C}_{x} \mathrm{~N}$ が得られる. 得られた $\mathrm{C}_{x} \mathrm{~N}$ 試料の組成, 結晶性, 形状, 窒素の存在状態をそれぞれ元 泰分析，X 線回折，SEM，TEM，XPS(黒鈶のC1s ピーク， $284.3 \mathrm{eV}$ を基準) で調べた。また比較のためにニッケル触媒

克都大学大学院工学研究科高分子化学専攻

( $=$ 606-01 京都市左京区吉田本町)

Division of Polymer Chemistry, Graduate School of Engineering, Kyoto University

(Yoshida Honmachi, Sakyo-ku, Kyoto 606-01, Japan)

Key Words: Carbon-Nitrogen Compound, Lithium Secondary Battery, Surface Oxidation
を用いないで $1000{ }^{\circ} \mathrm{C}$ で合成した $\mathrm{C}_{x} \mathrm{~N}$ ，ニッケル存在下 900 ${ }^{\circ} \mathrm{C}$ でベンゼンの熱分解によって得た炭素および天然黒鈶粉 末 (平均粒径 $7 \mu \mathrm{m}$ ) を実験に用いた. $\mathrm{C}_{x} \mathrm{~N}$ の酸化処理は $3 \mathrm{M}$, $6 \mathrm{M}, 10 \mathrm{M}\left(\mathrm{M}=\mathrm{mol} \mathrm{dm}^{-3}\right) \mathrm{HNO}_{3}$ 溶液を入れたビーカー中で スターラーでかきまだながら 12 時間行い，その後超音波を かけて更に 1 時間酸化した。酸化した $\mathrm{C}_{\boldsymbol{x}} \mathrm{N}$ は $120^{\circ} \mathrm{C} て ゙$ 半日 真空乾燥し, 実験に供した。

$\mathrm{C}_{x} \mathrm{~N}$ 試料 (3.3mg) にポリフッ化ビニリデンを $8 \mathrm{wt} \%$ けけ 加え，メノウの乳鉢でよく混合した後, 直径 $9 \mathrm{~mm}$ のろ紙上

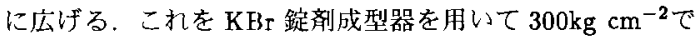
厚さ $0.1 \sim 0.2 \mathrm{~mm}$ のペレット状に加圧成型する.このペレッ トをステンレスメッシュにはさんで $300 \mathrm{~kg} \mathrm{~cm}^{-2} て ゙$ 加压して 作用極とした， $\mathrm{C}_{x} \mathrm{~N}$ ゆ充放電特性注金属りチウムを負極お よび参照極とする三栖式セルを用いて三菱化学(株) 製の $1 \mathrm{M}$ $\mathrm{LiClO}_{4}-\mathrm{EC} / \mathrm{DEC}(1: 1)$ 溶液中, $20 \mathrm{~mA} \mathrm{~g}^{-1}, 0 \sim 3 \mathrm{~V}$ の条件下 $20{ }^{\circ} \mathrm{C}$ で測定した.

\section{$3.1 \mathbf{C}_{\boldsymbol{x}} \mathbf{N}$ の組成, 掅造と結晶性}

\section{3 結果と考察}

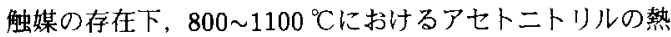
分解によって $\mathrm{C}_{14} \mathrm{~N} \sim \mathrm{C}_{60} \mathrm{~N}$ が生成し，とくに 900 1000 ${ }^{\circ} \mathrm{C}$ で窒素含有量の多い $\mathrm{C}_{14} \mathrm{~N} \sim \mathrm{C}_{21} \mathrm{~N}$ が得られた. 生成物には 約 7wt\%のニッケルが混じっていた，SEM，TEMによる形 状観祭より, 生成物は $800{ }^{\circ} \mathrm{C}$ では䋞維状 $\mathrm{C}_{x} \mathrm{~N}$ (直径約 $3 \mu \mathrm{m}$ および約 $0.3 \mu \mathrm{m}$ の 2 種類), $900{ }^{\circ} \mathrm{C}$ では緉維状 $\mathrm{C}_{x} \mathrm{~N}$ (直径約 $0.5 \mu \mathrm{m})$ と粉末状 $\mathrm{C}_{x} \mathrm{~N}($ 粒径 $2 \sim 3 \mu \mathrm{m})$ の混合物, $1000{ }^{\circ} \mathrm{C}$ では 粉末状 $\mathrm{C}_{x} \mathrm{~N}$ (粒径 2 $\left.3 \mu \mathrm{m}\right)$ であった.

触媒存在下で得た $\mathrm{C}_{x} \mathrm{~N}$ の X 線回折測定では通常の炭素材 料と同じ (002), (004), (100), (101), (110) 回折線が観察さ れ， $\mathrm{C}_{x} \mathrm{~N}$ が炭素と同じ層状構造を有すること，また $\mathrm{d}(002)$ が $0.335 \sim 0.337 \mathrm{~nm}$, (002) 回折線の半価幅が $1.25 \sim 0.60^{\circ}$, 之 くに $900^{\circ} \mathrm{C}$ 以上で得られた $\mathrm{C}_{x} \mathrm{~N}$ の半価幅は $0.90^{\circ}$ 以下で, ニッケル触媒を用いでに $1000{ }^{\circ} \mathrm{C}$ で合成した $\mathrm{C}_{14} \mathrm{~N}$ の d(002) $0.340 \mathrm{~nm}$, 半価幅 $2.85^{\circ}$ と比べていずれの值も小さく、ニッ ケル触媒を用いて合成した $\mathrm{C}_{x} \mathrm{~N}$ が良好な結晶性を有するこ とがわかった，酸化处理によって $\mathrm{C}_{x} \mathrm{~N}$ の組成， $\mathrm{d}(002)$ 值お よびその半価幅はほとんど变化しなかった．またべンゼンの 熱分解生成物の $\mathrm{d}(002)$ 值之 (002) 回折線の半価幅はそれぞ れ $0.337 \mathrm{~nm}, 0.94^{\circ}$ 『結晶性は $\mathrm{C}_{x} \mathrm{~N}$ と類似している. 
ニッケル触媒を用いて合成した $\mathrm{C}_{20} \mathrm{~N}$ と用いないで合成し た $\mathrm{C}_{14} \mathrm{~N}$ のN1sXPS スペクトルは大登く異なっており，炭素 シートの端に存在するピリジン型の空素は $398.9 \mathrm{eV}$ にピー クを有し, 炭素シートの内部の炭素原子と置換した空素を示 すピークは $400.9 \mathrm{eV}$ に現れる7)。ニッケル触媒を用いて合成 した $\mathrm{C}_{20} \mathrm{~N}$ では不可逆容量に関係するとされているピリジン 型の窒素が著しく少ないここが N1s スペクトルより明らか となった. 酸化処理前後における炭素シート内部の空素と周 辺に存在するピリジン型窒素の比に大:きな変化はみられない が, 窒素の総量は酸化処理によって幾分滅少するため, 上記 のN1s ピークはそれぞれ $398.1 \mathrm{eV}, 400.7 \mathrm{eV}$ にシフトし，窒 素に隣接した炭素に酸素が結合した結果生じたと思われる新 しいピークが $399.1 \mathrm{eV}$ に現れた。同時に $\mathrm{C}_{x} \mathrm{~N}$ 表面に存在す る酸素の量も增加していることがわかった.

\section{2 酸化処理 $\mathrm{C}_{\boldsymbol{x}} \mathrm{N}$ の充放電特性}

Fig.1，Fig.2に $900{ }^{\circ} \mathrm{C}$ で合成した $\mathrm{C}_{21} \mathrm{~N}$ 上酸化処理を施 した $\mathrm{C}_{21} \mathrm{~N}$ の充放電曲線とサイクル特性を示す．Fig.2には 天然黒銷粉末とニッケル触媒下ベンゼンの熱分解によって得
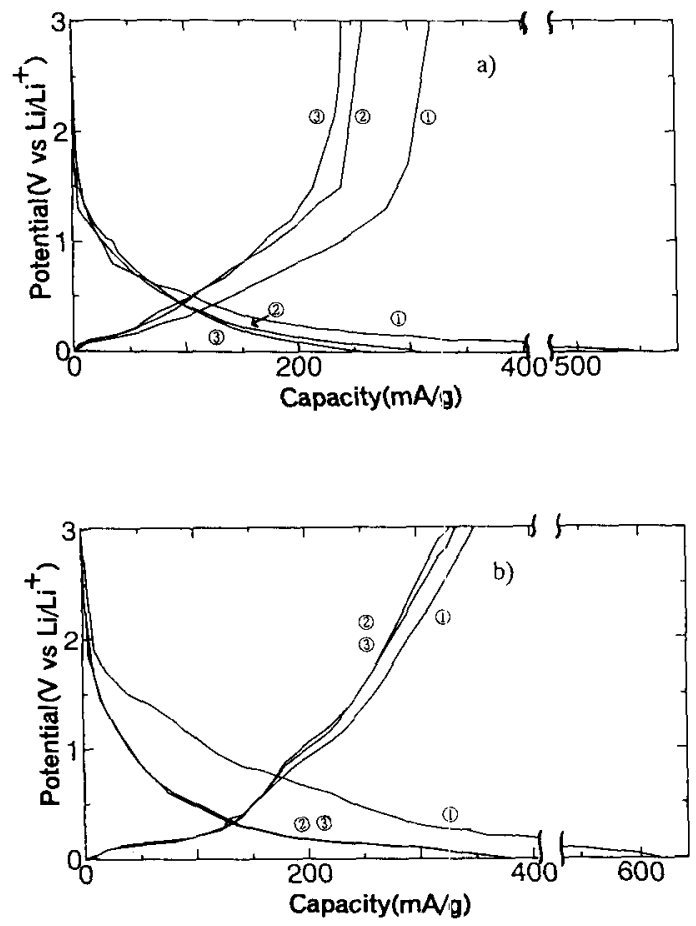

Fig.1 Charge-discharge curves for $\mathrm{C}_{21} \mathrm{~N}$ prepared by pyrolysis of acetonitrile at $900^{\circ} \mathrm{C}$ with $\mathrm{Ni}$ catalyst.

a) without treatment

b) treated by $6 \mathrm{M} \mathrm{HNO}_{3}$ solution

(1): 1 st cycle (2): 3 rd cycle (3): 6 th cycle

Current: $20 \mathrm{~mA} \mathrm{~g}^{-1}$

Electrolyte: $1 \mathrm{M} \mathrm{LiClO}_{4}-\mathrm{EC} / \mathrm{DEC}(1: 1)$
た炭素のサイクル特性も併せて示す， $\mathrm{C}_{21} \mathrm{~N}$ の充放電曲線は 高結晶性黒鉛の場合と異なり，紱やかに電位が上昇，下降す る曲楾を描き， $1.5 \mathrm{~V}$ 以上では充電曲線は急激な立ち上がり をみせた。 また充放電をくり返すにつれて容量が低下した。 これに対し，酸化処理 $\mathrm{C}_{21} \mathrm{~N}$ では $1 \mathrm{~V}$ から $3 \mathrm{~V}$ までほぼ直線 的に電位が上昇し，2 サイクル目以降は容量低下がほとんど

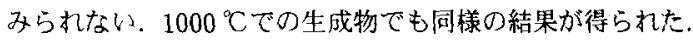
比較のために触媒を用いないで $1000{ }^{\circ} \mathrm{C}$ で得た $\mathrm{C}_{14} \mathrm{~N}$ の容量 はサイクル数の增加に伴って減少し，触媒を用いて $1000{ }^{\circ} \mathrm{C}$ で合成した $\mathrm{C}_{20} \mathrm{~N}$ の約 $80 \%$ であった，触媒存在下で得たベ ンゼンの熱分解生成物と $\mathrm{C}_{x} \mathrm{~N}$ の結晶性は類似しているので， 両者の充放電特性の違いは主に窒素の導入によるものと推 測され，また酸化処理による充放電特性の改善は酸素種の増 加によるリチウムイオンとの化学的相互作用や表面構造の 変化などが考えられるが, 今後より詳練な検討が必要である。

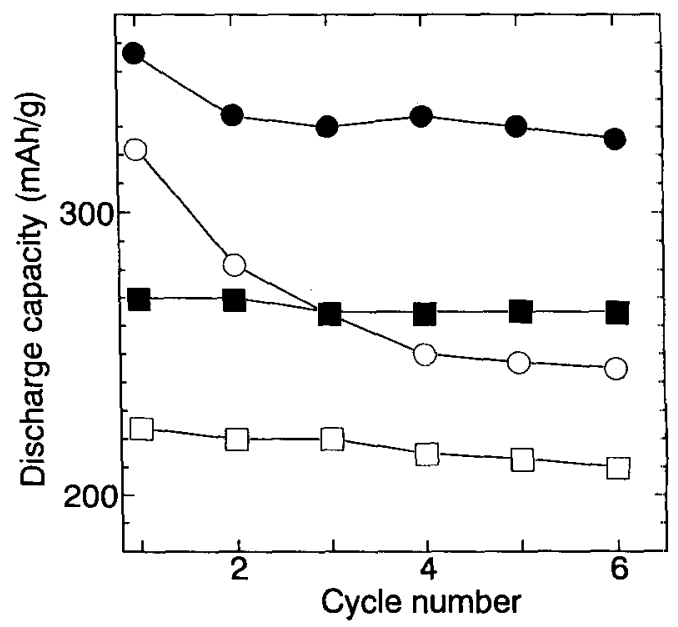

Fig.2 Discharge capacities of $\mathrm{C}_{x} \overline{\mathrm{N}}$ samples and carbons as a function of cycle number.

O: $\mathrm{C}_{21} \mathrm{~N}$ prepared at $900^{\circ} \mathrm{C}$ with $\mathrm{Ni}$ catalyst

: $\mathrm{C}_{21} \mathrm{~N}$ treated by $6 \mathrm{M} \mathrm{HNO}_{3}$ solution

$\square$ : Carbon prepared by pyrolysis of benzene at $900{ }^{\circ} \mathrm{C}$ with $\mathrm{Ni}$ catalyst

a: Natural graphite powder $(\approx 7 \mu \mathrm{m})$

Current : $20 \mathrm{~mA} \mathrm{~g}^{-1}$, Potential : $0 \sim 3.0 \mathrm{~V}$

\section{文献}

1) A. Mabuchi, Tanso, 165, 298 (1994).

2) 辰巳国昭，電池技術， 7,68 (1995).

3) M. Morita, T. Hanada, H. Tsutsumi, Y. Matsuda and M. Kawaguchi, J. Electrochem. Soc., 139, 1227 (1992).

4) M. Ishikawa, M. Morita, T. Hanada, Y. Matsuda and M. Kawaguchi, Denki Kagaku, 61, 1395 (1993).

5) B. M. Way and J. R. Dahn, J. Electrochem. Soc., 141, 907 (1994).

6) W. J. Weydanz, B. M. Way, T. van Buuren and J. R. Dahn, J. Electrochem. Soc., 141, 900 (1994).

7) J. R. Pels, F. Kapteijin, J. A. Mouljin, Q. Zhu and K. M. Thomas, Carbon, 33, 1641 (1995). 